\title{
Activation of Infectious Virus from Latent Human Immunodeficiency Virus Infection of Monocytes In Vivo
}

\author{
Judy A. Mikovits, * Nancy C. Lohrey, ${ }^{*}$ Richard Schulof, Jane Courtless, ${ }^{5}$ and Francis W. Ruscetti \\ ${ }^{*}$ Biological Carcinogenesis and Development Program, Program Resources/DynCorp, Inc.; ${ }^{\ddagger}$ Laboratory of Immunoregulation, \\ Biological Response Modifiers Program, National Cancer Institute-Frederick Cancer Research and Development Center, \\ Frederick, Maryland 21702-1201; and ${ }^{\S}$ AIDS Clinical Trials Unit, George Washington University \\ Medical Center, Washington, District of Columbia 20037
}

\begin{abstract}
Individuals infected with HIV may be asymptomatic for years before progressing to overt AIDS. Since HIV can latently infect monocytoid cell lines, we examined whether HIV latency occurs in monocytes in vivo. Freshly isolated monocytes from asymptomatic seropositive individuals examined before and after culture were positive for HIV DNA, but not RNA, as measured by polymerase chain reaction, showing that HIV latency occurs in monocytes in vivo. Coculture of these latently infected monocytes with Con A-activated T cells from HIVnegative normal donors stimulated $90 \%$ of the patients' samples and latently infected THP-1 to produce infectious virus. Neither Con A, resting T cells, nor $T$ cell supernatants induced virus. Plasma membranes from activated $T$ cells stimulated HIV production, suggesting cell contact induces factor(s) in monocytes to overcome latency. Thus, monocytes in AIDS patients harbor latent HIV inducible during an immune response, leading to $T$ cell infection and viral-induced pathology. (J. Clin. Invest. 1992. 90:1486-1491.) Key words: • human immunodeficiency virus $1 \cdot$ latency $\bullet$ monocytes $\bullet$ immune activation
\end{abstract}

\section{Introduction}

The two major cell types known to harbor HIV, the etiologic agent of AIDS, are the CD4 ${ }^{+} \mathrm{T}$ lymphocyte $(1-3)$ and the monocyte/macrophage (4-6). The recently described ability of both cell types to harbor microbiologically latent HIV (7-9) (no viral expression but remaining inducible to produce infectious virus) suggests a mechanism for viral persistence during the long asymptomatic period seen in $\operatorname{AIDS}(10,11)$. Although the selective depletion of the $\mathrm{CD}^{+}{ }^{+} \mathrm{T}$ cells in advanced AIDS results in increased susceptibility to opportunistic infections, neoplasia, and eventual death, the role of the HIV infected monocyte in the pathogenesis of AIDS has not been fully elucidated. It is clear that the monocyte/macrophage serves as a viral reservoir, as HIV has been detected in tissue macrophages of the brain and other organs $(12,13)$ as well as blood monocytes (4-6). Increasing evidence suggests that the monocyte/macrophage is mainly responsible for the neurological effects seen in AIDS (14-16).

Address correspondence to Dr. Francis Ruscetti, Laboratory of Molecular Immunoregulation, Building 560, Room 21-89A, P. O. Box B Frederick Cancer Research \& Development Center, Frederick, MD 21702-1201

Received for publication 13 December 1991 and in revised form 6 May 1992.

The Journal of Clinical Investigation, Inc.

Volume 90, October 1992, 1486-1491
Using the cell line THP-1 as a tissue culture model system, we have recently shown that HIV-1 can exist in a latent state for many months in monocytoid cells (9). This latent provirus could be activated to infectious virus by treatment with 5 -azacytidine. However, a variety of cytokines and other agents that increase viral expression in chronically infected cells (17-20) did not induce latent virus. These studies were extended to determine if physiological stimuli could induce expression of virus from latently infected THP-1 cells.

Recently, it was shown by Schrier et al. (21) that Con A-activated $\mathrm{T}$ cells could upregulate HIV expression in monocytes and provide a permissive host for HIV transmission during an immune response. We found that coculture of latently infected THP-1 cells with normal Con A-activated T cells also induced HIV expression from these latently infected cells. These results afforded us the opportunity to ask if latency occurs in monocytes in vivo as well as to test the physiological relevance of immune activation of latent HIV expression in monocytes of infected individuals and subsequent infection of $\mathrm{T}$ cells.

\section{Methods}

Cell lines. THP-1, L-THP-1 (THP-1 latently infected with HIV), 8E5 (a cell line containing one copy of HIV-1 DNA) (22), HUT-78, and HUT-102 cell lines were maintained in RPMI with $10 \%$ FCS, penicillin $(100 \mu \mathrm{g} / \mathrm{ml})$, streptomycin $(100 \mu \mathrm{g} / \mathrm{ml})$, and glutamine $(300 \mu \mathrm{g} / \mathrm{ml})$. Cells were subcultured 1:5 every 4-5 d.

Isolation of normal peripheral blood cells. Buffy coats from normal healthy donors were used as previously described (23). Briefly, mononuclear cells separated by Ficoll-Hypaque gradient centrifugation were depleted of monocytes by centrifugal elutriation. Highly purified $T$ cells were then isolated by nylon wool columns followed by discontinuous Percoll gradients as described (24). T cells were either activated with Con A $(5 \mu \mathrm{g} / \mathrm{ml})$ or PHA $(1 \mu \mathrm{g} / \mathrm{ml})$ for $48 \mathrm{~h}$, grown in IL-2-containing media or further separated into CD4+ and CD8+ subsets using magnetic bead technology as previously described (25).

Isolation of monocytes from blood of HIV-infected individuals. HIV-1 seropositive asymptomatic blood donors have CD4+ $\mathrm{T}$ cell counts and immunologic profiles within normal ranges and are either virus culture positive or negative $(26,27)$. PBMC were obtained from $30-50 \mathrm{ml}$ of peripheral blood of these donors, as described above. T cells were removed by complement depletion using OKT3 antibody; resuspended in RPMI supplemented with $5 \%$ human $\mathrm{AB}$ serum (Irvine Scientific, tested HIV negative, Irvine, CA) at $2-4 \times 10^{6} / \mathrm{ml}$ and adhered to six-well plates. At $24 \mathrm{~h}$, nonadherent cells were removed, saved for coculture and HIV analysis by polymerase chain reaction $(\mathrm{PCR})^{1}$ and $\mathrm{P} 24$ antigen. The adherent monolayers were washed thrice with PBS to remove loosely adherent cells. The cells in the monolayers consisted of $>95 \%$ esterase and Leu M3-positive, and $<1 \%$ CD3- and CD8-positive cells.

1. Abbreviations used in this paper: L THP-1, THP-1 cells latently infected with HIV-1; PCR, polymerase chain reaction. 
Phenotypic analysis of monocyte monolayers. Cytofluorometric analysis was performed as previously described (9). Leu 1 (CD3), Leu3A (CD4), LEU-2 (CD8), LEU-M3 (CD16) antibodies were obtained from Becton Dickinson \& Co. (Sunnyvale, CA).

Infections. $10^{7}$ cells in $\log$ phase growth were infected with $100 \mu \mathrm{l}$ of cell-free supernatants as previously described $(9,28)$. An isolate of HIV-1 obtained from activated T cells $(28)$ was used to infect both monocytoid cells (THP-1; reference 9) and T cells (Hut 78 and Hut 102 ; reference 28 ). Viral p24 antigen, as a measure of infectivity, was determined on tissue culture supernatants or on cell pellets lysed with $1 \%$ Triton X-100 by ELISA (Cellular Products, Buffalo, NY) according to the manufacturer's specifications with a sensitivity limit of 10 $\mathrm{pg} / \mathrm{ml}$.

$P C R$ analysis of RNA/DNA products. Nucleic acids were isolated by the guanidine thiocyanate method previously described (29). Amplification reactions of $1-5 \mu \mathrm{g}$ of either RNA $(30)$ or DNA $(31,32)$ contained $1.5 \mathrm{mM} \mathrm{MgCl}_{2}, 10 \mathrm{mM}$ Tris- $\mathrm{HCl}, \mathrm{pH} 8.3,50 \mathrm{mM} \mathrm{KCl}, 1$ $\mathrm{mM}$ of each four deoxynucleotides (Perkin Elmer Cetus, Emaryville, CA), $100 \mathrm{U}$ of M-MLV Reverse Transcriptase (Bethesda Research Laboratories, Bethesda, MD) (for RNA), 2.5 U AmpliTaq DNA polymerase, 1 U RNase Inhibitor for RNA (Promega Corp., Madison, WI), $0.01 \mathrm{M}$ DTT, and $1 \mu \mathrm{M}$ of each primer. Primer pairs used were as follows: SK38/38 HIV gag (1543-1570, 1630-1657) (31); Co11/12 HIV TAT splice product (8395-8414, 5955-5974) (32); and Gap 371/546 GAPDH (371-388, 546-565) (33). Amplification was carried out in a thermocycler (Perkin-Elmer Cetus), as described (3034). Probes used were SK19 HIV gag (1587-1627) Co11/12 HIV TAT (5975-5999); GAP514 GAPDH (514-532). Analysis of hybridized products was seen on a $10 \%$ nondenaturing acrylamide $/ 1 \times$ Trisacetate-EDTA gel by exposure to Kodak XAR- 5 film at $-70^{\circ} \mathrm{C}$ for 2-48 $\mathrm{h}$ (with intensifying screens).

Plasma membrane isolation. $48-60 \mathrm{~h}$. Con A-activated normal T

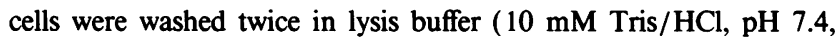
containing $1 \mathrm{mM} \mathrm{MgCl}$ and $1 \mathrm{mM} \mathrm{CaCl}_{2}$ ) and broken by dounce homogenation in lysis buffer equal to $1 \%$ the original volume. The cell-free lysate was centrifuged at $700 \mathrm{~g}$ for $10 \mathrm{~min}$. The pellet was washed once in lysis buffer and the two supernatants combined were then centrifuged at $5,000 \mathrm{~g}$ for $10 \mathrm{~min}$. The plasma membranes remain in the supernatant fluid, which was applied to a discontinuous sucrose gradient of $0.25,1.37,1.48,1.60 \mathrm{M}$, and centrifuged at $25,000 \mathrm{rpm}$ in a rotor (Beckman SW; Beckman Instruments, Fullerton, CA) for $4 \mathrm{~h}$. The plasma membranes, found at the $0.25-1.37 \mathrm{M}$ interface, are removed, diluted 1:4 with TK buffer ( $50 \mathrm{mM}$ Tris/ $\mathrm{HCl}, \mathrm{pH} 7.4 ; 5 \mathrm{mM}$ $\mathrm{MgCl}_{2} ; 5 \mathrm{mM} \mathrm{CaCl}_{2} ; 25 \mathrm{mM} \mathrm{KCl}$ ), and centrifuged at $70,000 \mathrm{~g}$ for 90 min. Membranes were used in the activation studies at a final concentration of $100 \mu \mathrm{g} / \mathrm{ml}$.

\section{Results}

Immune activation of THP-1 with latent HIV-1 infection. Since direct, HLA-DR-restricted interactions between $\mathrm{T}$ cells and monocytes are involved in many aspects of the immune response, we determined if $\mathrm{T}$ cells could induce HIV expression from latently infected THP-1 cells (LTHP-1). THP-1 cells have accessory cell function $(35,36)$ in that they can replace the requirement for monocytes in stimulating the proliferation of Con A-activated T cells, a response that is not HLA-DR restricted. Thus, LTHP-1 cells were cocultured for $7 \mathrm{~d}$ with purified normal (HIV-negative) donor T cells activated with Con A $48 \mathrm{~h}$ before coculture. Viral expression was measured by gene amplification using PCR technology (30-34). Normal Con A-activated T cells induced HIV RNA expression in LTHP-1 cells (Fig. 1, lane 3) using primers to both gag (Fig. 1) and spliced tat products of HIV-1 (data not shown). In contrast, coculture of LTHP-1 with a T cell line (Hut-102) or supernatants from Con A-activated $\mathrm{T}$ cells did not activate

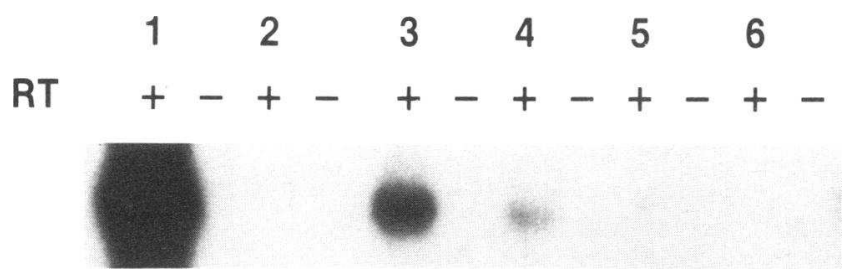

Figure 1. Activation of HIV-1 RNA expression in latently infected THP- 1 cells. RNA from LTHP- $1\left(1 \times 10^{5} / \mathrm{ml}\right)$ cocultured $7 \mathrm{~d}$ with equivalent numbers of Con A-activated $T$ cells ( conA/T) was isolated as described. 1 and $5 \mu \mathrm{g}$ (equivalent to $150,000-750,000$ cells) (32) were amplified as described in Methods. The oligomer hybridization autoradiography demonstrates the presence of amplified HIV-1 gag RNA (4-h exposure). Lane 1, 8E5 ( $1 \mu \mathrm{g})$; lane 2, LTHP-1 cells ( $5 \mu \mathrm{g}$ ); lane 3 , LTHP-1 cocultured with normal Con A/T ( 1 $\mu \mathrm{g})$; lane 4, LTHP-1 treated with LPS/5-azacytidine $(1 \mu \mathrm{g})$; lane 5, LTHP-1 cocultured with Hut-102 ( $5 \mu \mathrm{g})$; lane 6, LTHP-1 cultured with Con A/T cell supernatant $(5 \mu \mathrm{g})$.

viral expression (Fig. 1, lanes 5 and 6 ). Also, resting $T$ cells, CEM, and Hut-78 did not activate HIV expression. Using separated $T$ cell subsets, $C D 4+$ but not $C D 8+T$ cells activated latent HIV in LTHP-1 to produce infectious virus. T cells remaining in suspension after $7 \mathrm{~d}$ were removed, grown in IL-2, and found to be infected. Viral activation and spread to $T$ cells was seen by PCR-RNA by day 3 , reaching a peak by day 7 (data not shown).

$H I V-1$ RNA expression in monocytes from asymptomatic seropositive individuals. To test the physiological relevance of this latent model, we determined whether latency occurred naturally in monocytes from HIV-1 infected individuals. Adherent monolayers of monocytes obtained from blood of HIVseropositive asymptomatic individuals by $\mathrm{CD} 3+$ depletion and overnight adherence consisted of $>95 \%$ esterase- and Leu M3 positive- and $<1 \%$ CD3- and CD8-positive cells. Also, as previously shown (37), these adherent monocytes rapidly lose their CD4 positivity. The monolayers were cocultured with and without normal Con A-activated T cells for 7-10 d. After $10 \mathrm{~d}$, the adherent cells incubated in media alone remained CD3 and $\mathrm{CD} 4$ negative and Leu $\mathrm{M} 3$ positive with a differentiated monocytoid appearance, but now only $50-60 \%$ of the cells stained weakly for esterase as previously described $(21,37)$. The cocultured $T$ cells in suspension were removed from the adherent layer and supernatants assayed for p24 antigen. Monolayers were washed with PBS and nucleic acids were isolated as described in Methods.

The cells were then tested for HIV RNA expression. After reverse transcription of total RNA, cDNA was amplified by PCR (Fig. 2). Amplified products specific for HIV were detected only in the reverse-transcribed samples from monolayers incubated in the presence of Con A-activated $\mathrm{T}$ cells both for spliced tat (Fig. $2 A$, lanes 5 , 9, and 11 ; Fig. $2 B$, lanes 5,7 , and 9) or gag (data not shown). In contrast, monocyte monolayers incubated in media alone showed no HIV-specific amplified products (Fig. 2 A, lanes 4, 8, and 10; Fig. $2 B$ lanes 4, 6 , and 8 ) with the exception of patient 1 (Fig. $2 B$, lane 2 ). That RNA from monocytes incubated in media alone was amplified as efficiently as the other RNAs was shown in $18 / 19$ cases by amplification of glyceraldehyde-3-phosphate dehydrogenase (Fig. $2 C$ ). In $14 / 18$ cases where no viral expression was seen in monocytes cultured alone, RNA specific for tat and gag as well 
A

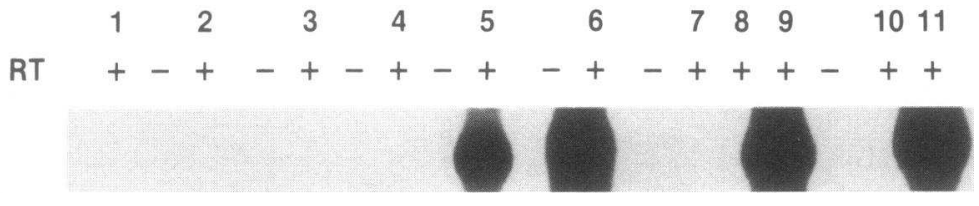

B

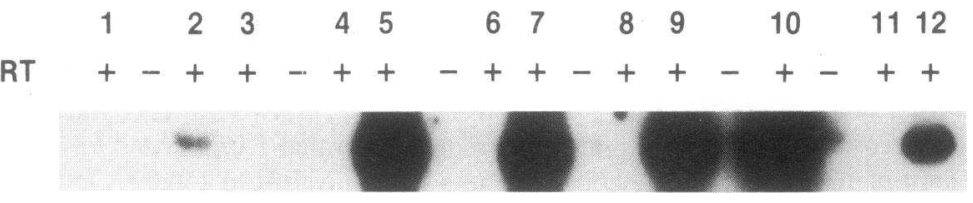

C

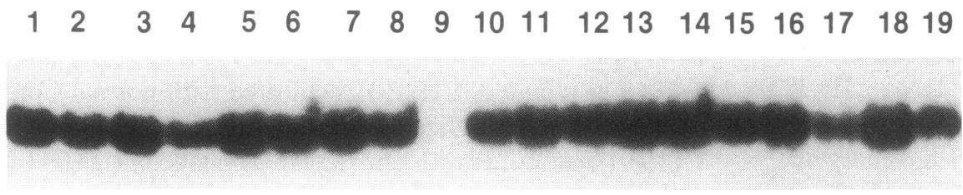

Figure 2. Detection of HIV RNA expression in adherent monocytes from HIV seropositive asymptomatic individuals. RNA from monocytes ( $1-5 \times 10^{6}$ cells) cultured $7 \mathrm{~d}$ as adherent monolayers was prepared as described. 1 and $5 \mu \mathrm{g}$ of total cellular RNA were subjected to RT-PCR as described. The oligomer hybridization autoradiography detecting amplified products (4-h exposure) is shown. $(A)$ Detection of HIV-spliced tat RNA. Lane 1, normal monocytes ( $5 \mu \mathrm{g}$ ); lane 2 , patient 5 control $(5 \mu \mathrm{g})$; lane 3 , patient 5 with con $\mathrm{A} / \mathrm{T}$ $(5 \mu \mathrm{g})$; lane 4, patient 6 control $(5 \mu \mathrm{g})$; lane 5 , patient 6 with con A/T $(1 \mu \mathrm{g})$, lane 6 , HIV-1-infected Hut $78(1 \mu \mathrm{g})$; lane 7 , Hut $78(5 \mu \mathrm{g})$; lane 8 , patient 7 control $(5 \mu \mathrm{g})$; lane 9 ; patient 7 with Con A/T $(1 \mu \mathrm{g})$; lane 10 , patient 8 control ( 5 $\mu \mathrm{g})$; lane 11 , patient 8 with Con A/T cells $(1 \mu \mathrm{g})$. Longer exposures had the same results. $(B)$ Detection of HIV-spliced tat RNA. Lane 1, normal monocytes $(5 \mu \mathrm{g})$; lane 2 , patient 1 control $(5$

$\mu \mathrm{g}$ ); lane 3, patient 9 control ( $5 \mu \mathrm{g})$; lane 4, patient 2 control ( $5 \mu \mathrm{g})$; lane 5, patient 2 with Con A/T ( $1 \mu \mathrm{g})$; lane 6 , patient 3 control ( $5 \mu \mathrm{g})$; lane 7, patient 3 with Con A/T cells, lane 8 , patient 4 control $(5 \mu \mathrm{g})$; lane 9, patient 4 with Con A/T cells ( $1 \mu \mathrm{g}$ ); lane 10 , infected Hut 78 ( 1 $\mu \mathrm{g})$; lane 11 , DNA from infected Hut $78(1 \mu \mathrm{g})$; lane 12, RNA and DNA from infected Hut $78(1 \mu \mathrm{g})$. Longer exposures yielded the same results. $(C)$ Detection of the cellular enzyme gylceraldehyde-3-phosphate-dehydrogenase. RNA from the first 19 samples of monocytes cultured alone is shown as an internal control of equivalent levels of amplifiable RNA added.

as extracellular p24 (30-250 pg/ml) (Table I) was seen after coculture with normal Con A-activated T cells. In addition, the normal $T$ cells cultured in IL-2 subsequent to the coculture were virus positive showing that the activated virus was infectious ( Table I).

HIV-DNA in monocytes from asymptomatic seropositive donors. Since these results suggest that HIV can exist in a latent state in monocytes of HIV-infected individuals, we next examined the HIV DNA status in these cells. Interestingly, PCR analysis of the DNA isolated from these monocytes revealed HIV-specific sequences for gag and tat in only 9 of 21 individuals (Fig. $3 A$ lanes 1, 6, and 8; Table II). However, DNA as well as RNA could be detected in the peripheral monocytes of 17 of 21 individuals after coculture with normal Con A T cells (Table I). The same four individuals were negative for both

Table I. Activation of HIV-1 Expression in Primary Monocytes

\begin{tabular}{clcccc}
\hline $\begin{array}{c}\text { Sample } \\
\text { totals }\end{array}$ & $\begin{array}{c}\text { Culture } \\
\text { treatment }\end{array}$ & DNA* $^{\text {RNA* }}$ & $\begin{array}{c}\mathrm{p} 24 \\
\text { Antigen }\end{array}$ & Infectivity \\
\hline & & & & $p g / m l$ & \\
3 & None & 3 & 3 & $100-250$ & ND \\
6 & None & 6 & 0 & 0 & $0 / 3$ \\
6 & Con A/T cells & 6 & 6 & $30-250$ & $3 / 3$ \\
12 & None & 0 & 0 & 0 & $0 / 6$ \\
12 & Con A/T cells & 8 & 8 & $30-250$ & $6 / 6$ \\
& & & & &
\end{tabular}

RNA/DNA from monocytes $\left(1-5 \times 10^{6}\right.$ cells $)$ cultured $7 \mathrm{~d}$ as adherent monolayers in the presence and absence of equivalent numbers of Con A-activated T cells was isolated as described. 1 and $5 \mu \mathrm{g}$ of total cellular RNA/DNA was added to the reaction mixture and subjected to 30 cycles PCR amplification. $2 \times 10^{6}$ cells were detergent disrupted for HIV p24 antigen by ELISA, which was performed as described in Methods. Viral transmission to Hut-102 was used as a measure of infectivity. ${ }^{*}$ Number of positive occurrences.
DNA and RNA. Primers for GAPDH show that the amplification of the DNA samples was of similar magnitude (data not shown ). The limit of detection in our system as determined by PCR on serial dilutions of the 8E5 cell line was 1 infected cell / 100,000 cells (Fig. $3 \mathrm{~B}$ ). This sensitivity is the same as that previously reported $(34,38)$. Diluting the test DNA sample with $1 \mu \mathrm{g}$ of uninfected DNA did not affect the sensitivity of the assay (data not shown). These results indicate that the HIV-1

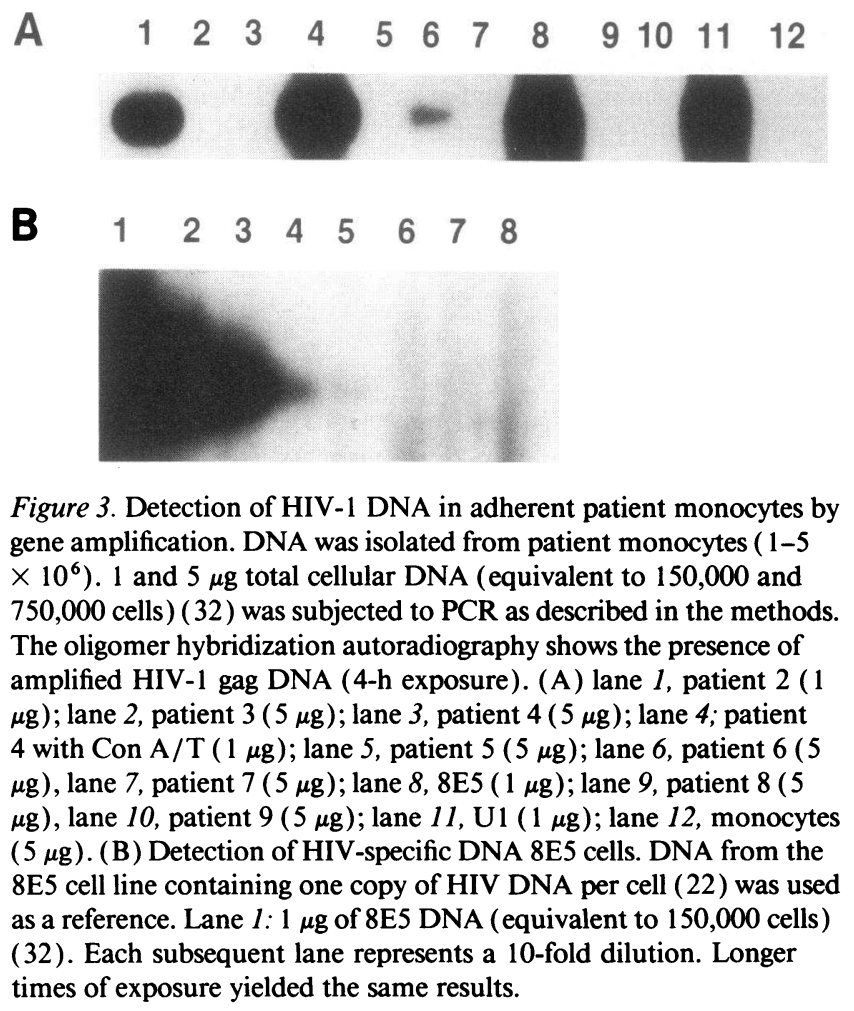


Table II. Comparison of Latent HIV Transmission to T cells and Hut-102

\begin{tabular}{|c|c|c|c|}
\hline \multirow[b]{2}{*}{ Cells } & \multirow{2}{*}{$\begin{array}{l}\text { Primary } \\
\text { coculture }\end{array}$} & \multicolumn{2}{|c|}{ Second coculture } \\
\hline & & $\mathrm{T}$ cells & Hut-102 \\
\hline \multicolumn{4}{|l|}{ Cell lines } \\
\hline Latent THP-1 & None & - & - \\
\hline Latent THP-1 & HUT-102 & - & - \\
\hline Latent THP-1 & LPS/5 AZA C & + & + \\
\hline Latent THP-1 & Con $\mathrm{A} / \mathrm{T}$ cells & + & + \\
\hline U1 & None & + & + \\
\hline \multicolumn{4}{|c|}{ Patients 7,11 , and 12} \\
\hline Monocytes & None & - & - \\
\hline Monocytes & Con $\mathrm{A} / \mathrm{T}$ cells & + & + \\
\hline Monocytes & HUT-102 & - & - \\
\hline Monocytes & Con A/Hut 102 & - & - \\
\hline
\end{tabular}

1-5 $\times 10^{6}$ monocytes or LTHP- 1 cocultured $7 \mathrm{~d}$ with the equivalent number of T cells. Viral transmission to Hut-102 and PHA-activated $T$ cells as a measure of viral production was performed on cell-free supernatants and assessed as described in Methods. Infectivity was determined by the presence of HIV nucleic acids detected by PCR amplification of 1 and $5 \mu \mathrm{g}$ of RNA. $2 \times 10^{6}$ detergent-disrupted cells were used for HIV p24 antigen detected by ELISA.

provirus was latent in the peripheral monocytes of these infected individuals but that levels of HIV DNA in eight monocyte cultures inducible for viral expression were below the detectable limits of the PCR analysis. Despite the low levels of latently infected monocytes in these cultures, the cells could still be induced by uninfected Con A-activated T cells to produce infectious virus.

Mechanism of immune activation of HIV-1 from latently infected monocytes. Next, the nature of the immune activation was further studied. For HIV activation from patient monocytes, partially purified plasma membranes from Con A-activated $\mathrm{T}$ cells could replace the need for whole cells (Fig. $4 \mathrm{~A}$, lane 11). To determine if proliferating normal $\mathrm{T}$ cells were needed, parallel cocultures of patients' monocytes were set up with either Hut-102 or Con A-activated normal T cells. Hut102 cells were not infected (Fig. $4 A$ lanes 5 and 8 ) whereas parallel cultures with activated $\mathrm{T}$ cells were virus positive (Fig. $4 A$, lanes 6 and 9). In addition, coculture of LTHP-1 with Hut-102 did not result in viral activation even after 6 wk of cocultivation (Fig. $4 \mathrm{~A}$, lane 3 ). It was possible that Hut-102 cells were neither sensitive for HIV-1 transmission nor permissive to infection by the strain in patients' monocytes. However, we could consistently detect $10 \mathrm{U} 1$ infected cells cocultured for $7 \mathrm{~d}$ per $1 \times 10^{7}$ normal monocytes using Hut-102 (Fig. $4 \mathrm{~A}$, lane 13), but not one infected cell (Fig. 4, $A$, lane 12). In addition, to demonstrate that this viral activation resulted in production of virus that could infect Hut-102, viral transmission experiments using supernatants from these original cocultures were performed using Hut-102 and activated T cells as secondary cocultures ( Table II). In every case where activated virus was detected in the supernatants of stimulated monocytes, this virus could be subsequently transmitted cell free to both activated T cells and Hut 102 ( Table II ). In contrast, none of the initial Hut-102 cocultures activated virus. Thus, these data show that HIV was truly latent in these monocytes and suggests that activated $\mathrm{T}$ cells interact with monocytes differently than the T cell line Hut-102. Furthermore, these results indicate that the detected virus was not passively adsorbed to the surface of these monocytes and infecting the $T$ cells during the coculture period.

The possibility that the HIV expression came from a small percentage of either contaminating $\mathrm{T}$ cells or virus-producing cells present in the adherent monocyte monolayers cannot be completely ruled out. This is highly unlikely as Con A alone activated virus from $T$ cells and not from monocytes of these donors (data not shown). Also, in these monocyte cultures, no CD3 + cells could be identified after $10 \mathrm{~d}$ of culture, indicating that rare patient $\mathrm{T}$ cells were not activated to proliferate by a heterologous mixed lymphocyte reaction. In addition, LPS and cytokines known to increase HIV production (17-20) did not stimulate viral production in these monocytes (Table II). These results provide strong evidence that neither contaminating $\mathrm{T}$ cells nor virus-producing cells are responsible for the HIV expression induced in these monocytes.

Next, the conditions necessary for $T$ cells to activate latent virus were studied. First, cell contact was required, as Con Aactivated normal $T$ cells seeded into chambers with $4-\mu \mathrm{m}$ porefiltered bottoms placed into culture wells previously seeded with adherent patient monocytes failed to activate virus (Fig. 4 $B$, lane 8 ). In addition, supernatants from Con A-activated T cells could not stimulate HIV expression (Fig. $4 \mathrm{~B}$, lanes 4 and

A

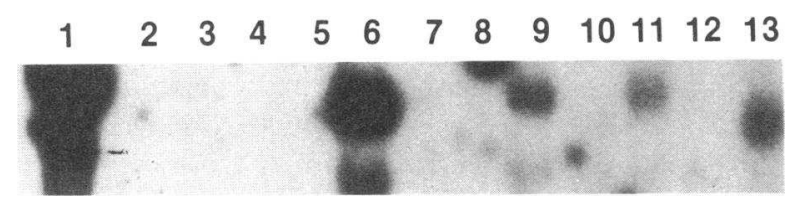

B

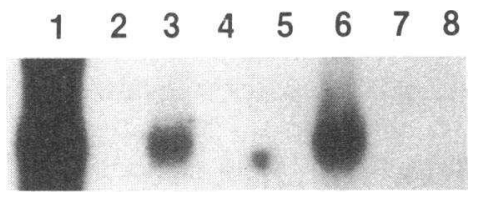

Figure 4. Activation of HIV RNA expression from latently infected monocytes from HIV-seropositive asymptomatic donors. RNA from monocytes $\left(1-5 \times 10^{6}\right)$ was prepared as described. 1 and $5 \mu \mathrm{g}$ of RNA were subjected RT-PCR amplification as described in the methods. The oligomer hybridization autoradiography of amplified HIV-1 spliced tat RNA product (4-h exposure) is shown. $(A)$ Lane 1, 8E5 (1 $\mu \mathrm{g})$; lane 2, normal monocytes ( $5 \mu \mathrm{g})$; lane 3, LTHP-1 with Hut-102 $(5 \mu \mathrm{g})$; lane 4, Hut-102 $(5 \mu \mathrm{g})$; lane 5 , patient 18 with Hut102; $5 \mu \mathrm{g}$; lane 6, patient 18 with Con A/T $(1 \mu \mathrm{g})$; lane 7, patient 18 control $(5 \mu \mathrm{g})$; lane 8 , patient 19 with Hut-102 $(5 \mu \mathrm{g})$; lane 9 , patient 19 with Con A/T ( $1 \mu \mathrm{g})$; lane 10, patient 19 control ( $5 \mu \mathrm{g})$; lane 11; patient 19 with membranes from Con A/T $(100 \mu \mathrm{g} / \mathrm{ml})(1 \mu \mathrm{g})$; lane $12,1 \mathrm{U} 1 \mathrm{cell} /$ monocytes with $10^{6}$ Hut-102 $(1 \mu \mathrm{g})$; lane $13 ; 10 \mathrm{U} 1$ cells with $10^{6}$ Hut-102 $(1 \mu \mathrm{g})$. (B) Lane 1 , 8E5 $(1 \mu \mathrm{g})$; lane 2, patient 11 control $(5 \mu \mathrm{g})$; lane 3 , patient 11 with Con A/T $(1 \mu \mathrm{g})$; lane 4 , patient 11 with supernatant from Con $\mathrm{A} / \mathrm{T}(5 \mu \mathrm{g})$; lane 5 , patient 12 control ( $5 \mu \mathrm{g})$; lane 612 with Con A/T ( $1 \mu \mathrm{g})$; lane 7, patient 12 with supernatant from Con $\mathrm{A} / \mathrm{T}$ cells $(5 \mu \mathrm{g})$; lane 8 , patient 12 with transwell membrane separated Con A/T cells $(5 \mu \mathrm{g})$. Longer exposures yielded the same results. 
7). Infectious virus was found in media from activated $T$ cell plasma membrane-treated monocytes. However, no virus was detected in the media of patients' monocytes cultured with unactivated $\mathrm{T}$ cells, Con $\mathrm{A}$ alone, cytokine-rich $\mathrm{T}$ cell supernatant, purified cytokines such as Colony-stimulating factor-1, granulocyte macrophage colony-stimulating factor, tumor necrosis factor- $\alpha$, and IL-6, or media controls. These results suggest that cell contact is required to activate factor(s) in the monocyte responsible for overcoming HIV latency.

\section{Discussion}

In agreement with Schnittman et al. (38), we found no HIVspecific DNA by PCR in 12/21 samples of patients' monocytes. However, expression of infectious HIV was induced in $8 / 12$ of those samples after coculture with Con A-activated T cells. The limit of detection in our system as determined by PCR performed on serial dilutions of the $8 \mathrm{E} 5$ cell line was found to be 1 infected cell / 100,000 cells, similar to previous reports $(34,38)$. These results indicate that the HIV-1 provirus was latent in the peripheral monocytes of these infected patients but that levels of HIV DNA in some cultures inducible for viral expression were below the detectable limits of the PCR analysis.

Despite the low levels of latently infected monocytes in these cultures, the cells could still be induced by uninfected Con A-activated $\mathrm{T}$ cells to produce infectious virus. These and identical results with LTHP-1 indicate that fully competent HIV can be latent in patient monocytes in vivo. However, three alternatives were considered and investigated: that HIV is passively adsorbed to monocytes; that contaminating viralproducing cells, either $\mathrm{T}$ cells or monocytes, are responsible for viral spread; and that a very small number of contaminating latent $T$ cells $(7,8)$ are being activated. The first two possibilities were ruled out conclusively by the sensitivity of the coculture experiments shown herein.

In regard to the presence of latently infected $T$ cells, it has been recently shown that in asymptomatic seropositive donors 1 in every 500 or $1,000 \mathrm{~T}$ cells is latently infected (39). Since we plated approximately 100,000 monocytes with $>1 \%$ CD3 positivity, at most there could only be 1-2 latently infected $T$ cells in each culture. Furthermore, when semipurified membranes were used to activate virus after 7-10 $\mathrm{d}$ of incubation, CD3+ positive cells were not detectable in the cultures, ruling out expansion of $\mathrm{T}$ cells by heterologous mixed lymphocyte reaction. Also, Con A and PHA, which can activate HIV from latently infected $T$ cells $(7,8)$, activated virus from $T$ cells but not from monocytes of these donors even when sufficient permissive cells were cocultured to amplify viral production ( Table II). These results provide strong evidence that contaminating $\mathrm{T}$ cells are not responsible for the HIV induced in these monocytes.

These studies confirm and extend those of Schrier et al. (21), who showed that Con A-activated autologous cells or autologous plus allogeneic cells could stimulate HIV production from macrophages. Similarly, the recent finding of McElrath et al. (40) showing the presence of HIV DNA in monocytes of AIDS patients in samples obtained up to 9 mo apart suggests that continuous infection of monocytes is occurring. However, in these studies, no conclusion can be made about viral latency. Also, recent studies $(41,42)$ have shown viral DNA in patients by PCR for up to $5 \mathrm{yr}$ before seroconversion, suggesting long-lived viral latency. We show for the first time that latency occurs in monocytes in vivo and that Con A-activated $T$ cells can activate this latent virus. The intimate relationship between $T$ cells and monocytes suggests that these cells could be infecting each other during the immune response by activating latent virus.

The cellular requirements of activation of latent HIV from monocytes were also studied. In LTHP-1 and latently infected patients' monocytes, activated CD4+ $\mathrm{T}$ cells but not CD8+ cells, resting $T$ cells, or Hut-102 could activate latent virus leading to a productive cytopathic infection. Plasma membranes from activated $T$ cells can stimulate monocytes to produce infectious virus, suggesting that cell contact is needed to activate factor(s) in the monocyte responsible for overcoming HIV latency. Although T cell signals involved are not known, activated $T$ cells provide different signals than resting $T$ cells or Hut-102. On activated cells, adhesion molecules like LFA-1 have higher affinity for binding to monocytes. Multiple accessory molecules (CD2, CD28) involved in T cell activation, which bind and signal antigen presenting cells, are candidates (43).

The presence of silently infected monocytes capable of producing virus during an immune response has some therapeutic implications. Since these latently infected monocytes may become long-lived tissue macrophages, it would be difficult to eliminate these cells. Thus, it would be important to determine whether a combination of immune stimulation plus antiviral therapy is capable of eliminating latently infected monocytes. Such an approach could make currently available antiviral agents more effective in vivo by eliminating an important reservoir of virus that may intermittently reactivate and infect uninfected $\mathrm{T}$ cells.

\section{Acknowledgments}

We thank Ms. Faye Perfalls, Susan LeLacheur, and the entire staff of the clinical trials unit at The George Washington University Medical Center for their enthusiastic recruitment of donors for this study. In addition, we also thank Drs. Dan Longo and Joost Oppenheim for their critical review of this manuscript. We also gratefully acknowledge the cooperation and generosity of the patients, without whom this study could not have been undertaken.

This project was funded in part with Federal funds from the Department of Health and Human Services under contract number N01-CO74102. The content of this publication does not necessarily reflect the views or policies of the Department of Health and Human Services, nor does mention of trade names, commercial products, or organizations imply endorsement by the U. S. Government.

\section{References}

1. Barre-Sinoussi, F., J.-C. Chermann, F. Rey, M. T. Nugeyre, S. Chamaret, J. Gruest, C. Dauguet, C. Axler-Blin, F. Vezinet-Brun, C. Rouzioux, et al. 1983. Isolation of a T-lymphotropic retrovirus from a patient at risk for acquired immunodeficiency syndrome (AIDS). Science (Wash. DC). 220:868-871.

2. Hoxie, J. A., N. Pillsbury, and J. A. Levy. 1985. Persistent moncytopathic infection of normal human $\mathrm{T}$ lymphocytes with AIDS-associated retrovirus. Science (Wash. DC.). 229:1400-1402.

3. Zagury, D., J. Bernard, R. Leonard, R. Cheynier, G. Feldman, P. S. Saren, and R. C. Gallo. 1986. Long-term cultures of HTLV-III infected T cells: a model of cytopathology and T cell depletion in AIDS. Science (Wash. DC). 231:850853. 
4. Nicolson, J. K., G. D. Cross, C. S. Callaway, and J. S. McCongal. 1986. In vitro infection of human monocytes with human $\mathrm{T}$ lymphotropic virus type III/lymphadenopathy-associated virus (HTLV-III/LAV). J. Immunol. 137:323-329.

5. Ho, D. D., T. R. Trota, and M. S. Hirsch. 1986. Infection of monocyte/macrophages by human T lymphotropic virus type III. J. Clin. Invest. 77:1712-1715

6. Gendelman, H. E., J. M. Orenstein, M. A. Martin, C. Ferrua, M. Mitra, T. Phipps, L. Wahl, H. C. Lane, A. S. Fauci, D. S. Burke, et al. 1988. Efficient isolation and propagation of human immunodeficiency virus on recombinan colony-stimulating factor 1-treated monocytes. J. Exp. Med. 167:1428-1441.

7. Stevenson, M., T. L. Stanwick, D. P. Dempsey, and C. A. Lamonica. 1990. HIV-1 replication is controlled at the level of $\mathrm{T}$ cell activation and proviral integration. EMBO (Eur. Mol. Biol. Organ.) J. 9:1551-1560.

8. Zack J. A., S. J. Arrigo, S. R. Weitsman, A. S. Go, A. Haislip, and I. S. Y Chen. 1990. HIV-1 entry into quiescent primary lymphocytes: molecular analysis reveals a labile, latent viral structure. Cell. 61:213-222.

9. Mikovits, J. A., Raziuddin, M. A. Gonda, M. Ruta, N. C. Lohrey, H.-F. Kung, F. W. Ruscetti. 1990. Negative regulation of HIV replication in monocytes. Distinctions between restricted and latent expression in THP-1 cells. $J$ Exp. Med. 171:1705-1720.

10. Blattner, W. A., R. J. Biggar, S. W. Weiss, M. Melbye, and J. J. Goedert. 1985. Epidemiology of human T-lymphotropic virus type III and the risk of the acquired immunodeficiency syndrome. Ann. Intern. Med. 103:665-670.

11. Ranki, A., S. L. Valle, M. Krohn, J. Antonen, J. P. Allain, M. Leuther, G. Franchini, and K. Krohn. 1987. Long latency precedes overt seroconversion in sexually transmitted human immunodeficiency-virus infection. Lancet. ii:589593.

12. Koenig, S., H. E. Gendelman, J. M. Orenstein, M. C. DalCanto, G. H. Pezeshkpour, M. Yungbluth, F. Janotta, A. Aksamit, M. A. Martin, and A. S. Fauci. 1986. Detection of AIDS virus in macrophages in brain tissue from AIDS patients with encephalopathy. Science (Wash. DC). 233:1089-1093.

13. Epstein, L., L. Sharer, E.-S. Cho, M. Meyenhofer, B. Navia, and R. Price 1985. HTLV-III/LAV-like retrovirus particles in the brains of patients with AIDS encephalopathy. AIDS Res. Ther. 1:447-454.

14. Guilian, D., K. Vaca, and C. A. Noonan. 1990. Secretion of neurotoxins by mononuclear phagocytes infected with HIV-1. Science (Wash. DC). 250:1593-1596.

15. Watkins B. A., H. H. Dorn, W. B. Kelly, R. C. Armstrong, B. J. Potts, F. Michaels, C. V. Kufta, and M. Dubois-Dalcq. 1990. Specific tropism of HIV for microglial cells in primary human brain cultures. Science (Wash. DC). 249:549553.

16. Pulliam, L., B. G. Herndier, N. M. Tang, and M. S. McGrath. 1991. Human immunodeficiency virus-infected macrophages produce soluble factors that cause histological and neurochemical alterations in cultured human brains. J. Clin. Invest. 87:503-512.

17. Folks, T., D. M. Powell, M. M. Lightfoote, S. Benn, M. A. Martin, and A. S. Fauci. 1986. Induction of HTLV-III/LAV from a nonvirus-producing Tcell line: implications for latency. Science (Wash. DC). 231:600-602.

18. Folks, T. M., J. Justement, A. Kinter, S. Schnittman, J. Orenstein, G. Poli, and A. S. Fauci. 1988. Characterization of promonocyte clone chronically infected with HIV and inducible by 13-phorbol-12-myristate acetate. J. Immunol. 140:1117-1122.

19. Folks, T. M., J. Justement, A. Kinter, C. A. Dinarello, and A. Fauci. 1987. Cytokine-induced expression of HIV-1 in a chronically infected promonocyte cell line. Science (Wash. DC). 238:800-802.

20. Clouse, K., D. Powell, I. Washington, G. Poli, K. Strebel, W. Farrar, P. Barstad, J. Kovacs, A. S. Fauci, and T. M. Folks. 1989. Monokine regulation of human immunodeficiency virus-1 in a chronically infected T cell clone. J. Immunol. 142:431-438.

21. Schrier, R., J. A. McCutchan, J. C. Venable, J. Nelson, and C. Wiley. 1990. T-cell-induced expression of human immunodeficiency virus in macrophages. J. Virol. 64:3280-3288.

22. Folks T. M., D. Powell, M. Lightfoote, S. Koenig, A. S. Fauci, S. Benn, A. Rabson, D. Daugherty, H. Gendleman, M. D. Hoggan, et al. 1986. Biological and biochemical characterization of a cloned Leu3- cell surviving infection with the acquired immune deficiency syndrome retrovirus. J. Exp. Med. 164:280-290.

23. Timonen, T., J. Ortaldo, and R. Herberman. 1981. Characterization of human large granular lymphocytes and relationship to natural killer and $\mathrm{K}$ cells. J. Exp. Med. 153:569-582.

24. Ortaldo, J., A. Mason, J. O'Shea, M. Smyth, L. Falk, I. Kennedy, D. Longo, and F. Ruscetti. 1991. Mechanistic studies of transforming growth factor$\beta$ inhibition of Il-2 dependent activation of CD3- large granular lymphocyte functions. J. Immunol. 146:3791-3798.

25. Geller, R., M. Smyth, S. Strobl, F. Bach, F. Ruscetti, D. L. Longo, and A. Ochoa. 1991. Generation of lymphokine-activated killer activity in T cells: possible regulatory circuits. J. Immunol. 146:3280-3288.

26. Levy, J., and J. Shimabukuro. 1985. Recovery of AIDS-associated retroviruses from patients with AIDS or AIDS-related conditions and from clinically healthy individuals. J. Infect. Dis. 152:734-738.

27. Ward, J. W., A. J. Grindon, P. M. Feorino, C. Schable, M. Parvin, and J. R. Allen. 1985. Laboratory and epidemiologic evaluation of an enzyme immunoassay for antibodies to HTLV-III. J. Am. Med. Assoc. 256:357-366.

28. Ruscetti, F. W., V.S. Kalyanaraman, R. Overton, J. Mikovits, H. Stevenson, K. Stromberg, R. B. Herbermnan, W. L. Farrar, and J. R. Ortaldo. 1986 Analysis of effector mechanisms against HTLV-I and HTLV-III/LAV infected lymphoid cells. J. Immunol. 136:3619-3624.

29. Chirgwin, J. M., A. E. Przybyla, R. J. MacDonald, and W. J. Rutter. 1979. Isolation of biologically active ribonucleic acid from sources enriched in ribonuclease. Biochemistry 18:5294-5299.

30. Byrne, B., J. Li, J. Sninsky, and B. Poiesz. 1988. Detection of HIV RNA sequences by in vitro DNA amplications. Nucleic Acids Res. 16:4165-4168.

31. Kwok, S., G. Ehrich, B. Poiesz, R. Kalish, and J. Sninsky. 1988. Enzymatic amplications of HTLV-1 viral sequences from peripheral blood mononuclear cells and infected tissues. Blood. 72:1117-1126.

32. Hewlett, I. K., M. Ruta, K. Cristiano, C. A. Hawthorne, and J. S. Epstein. 1989. Co-amplification of multiple regions of HIV-1 genome by the polymerase chain reaction: potential use in multiple diagnosis. Oncogene. 4:1149-1154.

33. Gendelman, H., R. Friedman, S. Joe, L. Baca, J. Turpin, G. Dveksler, M. Meltzer, and C. Dieffenbach. 1990. A selective defect of interferon-alpha production in human immunodeficiency virus-infected monocytes. J. Exp. Med. 172:1433-1442

34. Poiesz, B. J., G. D. Ehrlich, B. C. Byrne, K. Wells, S. Kwok, and J. Sninsky. 1990. The use of polymerase chain reaction in the detection, quantification, and characterization of human retroviruses. In Medical Virology. L. M. de la Maza and E. M. Peterson, editors. Plenum Press, New York. 47-72.

35. Tsuchiya, S., M. Yamabe, Y. Yamaguchi, Y. Kobyashi, T. Konno, and K. Tada. 1980. Establishment and characterization of a human acute monocytic leukemia cell line (THP-1). Int. J. Cancer. 23:171-176.

36. Tsuchiya, S., Y. Kobyashi, Y. Goto, H. Okumura, S. Nakae, T. Konno, and $\mathrm{K}$. Tada. 1982. Induction of maturation in cultured human monocytic leukemia cells by phorbol diester. Cancer Res. 42:1530-1536.

37. Crowe, S., J. Mills, M. McGrath, P. Lekas, and N. McManus. 1987. Quantitative immunocytofluorographic analysis of CD4 surface antigen expression and HIV infection of human peripheral blood monocyte/macrophages. AIDS Res. 3:135-145.

38. Schnittman, S. M., M. C. Psallidopoulos, H. C. Lane, L. Thompson, M. Baseler, F. Massari, C. Fox, N. Salzman, and A. Fauci. 1989. The resevoir for HIV-1 in human peripheral blood is a T cell that maintains expression of CD4. Science (Wash. DC). 245:305-308.

39. Bukrinsky, M. I., T. L. Stanwick, M. P. Dempsey, and M. Stevenson. 1991. Quiescent T lymphocytes as an inducible reservoir in HIV-1 infection. Science (Wash. DC). 254:423-427.

40. McElrath, R. Steinman, and Z. A. Cohn. 1991. Latent HIV-1 infection in enriched populations of blood monocytes and $\mathrm{T}$ cells from seropositive patients. J. Clin. Invest. 87:27-30.

41. Imagawa, D., M. Lee, S. Wolinsky, K. Sano, F. Morales, S. Kwok, J. Sninsky, P. Nishanian, J. Giorgi, J. Fahey, et al. 1989. Human immunodeficiency virus type 1 infection in homosexual men who remain seronegative for prolonged periods. N. Engl. J. Med. 320:1458-1462.

42. Nagao, T., K. Honda, N. Yoshihara, and K. Nakanaga. 1991. Delayed human immunodeficiency virus-1 seroconversion in a hemophilia $B$ patient in Japan. Blood. 78:1893-1894.

43. van Seventer, G., Y. Shimizu, and S. Shaw. 1991. Roles of multiple accessory molecules in T-cell activation. Curr. Opin. Immunol. 3:294-303. 